
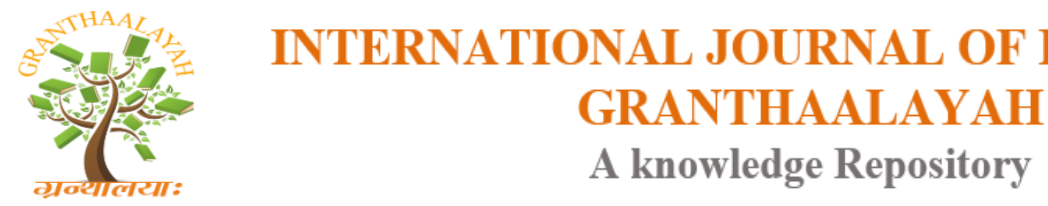

Management

\title{
THE RELATIONSHIP OF INNOVATION WITH ORGANIZATIONAL PERFORMANCE
}

\author{
Abdul karim Suhag ${ }^{1}$, Shafique Rahman Solangi ${ }^{2}$, Raja Sohail Ahmed Larik ${ }^{3}$, \\ Muhammad Kamil Lakho ${ }^{4}$, Altaf Hussain Tagar ${ }^{5}$ \\ ${ }^{1}$ Department of Education Sindh Madressatul Islam University Karachi, Pakistan \\ ${ }^{2}$ Lecturer of International Relations, Pakistan Navy School of Management, Karachi, Pakistan \\ ${ }^{3}$ Department of Computer science Shah Abdul Latif University Khairpur Mir's, Pakistan \\ ${ }^{4}$ Department of Media studies \& Social Science Sindh Madressatul Islam University Karachi, \\ Pakistan \\ ${ }^{5}$ Department of International Relations Shah Abdul Latif University Khairpur Mir's, Pakistan
}

DOI: https://doi.org/10.29121/granthaalayah.v5.i2.2017.1741

\begin{abstract}
This research study investigates the relationship of innovation with organizational performance of the telecommunication sector. The independent variables are process innovation, product innovation and organizational innovation as an organizational culture as moderating variable. The research is survey research in which questionnaire is administered to 200 employees that are concerned with innovation in telecom industry present in Islamabad and Rawalpindi to ensure reasonable response. The data was analyzed through the SPSS v.20 software. Results showed that product innovation, process innovation and organizational innovation has a positive impact on organization performance.
\end{abstract}

Keywords: Innovation; Organization Culture; Organization Performance; Telecom Sector Pakistan.

Cite This Article: Abdul karim Suhag, Shafique Rahman Solangi, Raja Sohail Ahmed Larik, Muhammad Kamil Lakh, and Altaf Hussain Tagar. (2017). "THE RELATIONSHIP OF INNOVATION WITH ORGANIZATIONAL PERFORMANCE." International Journal of Research - Granthaalayah, 5(2), 292-306. 10.29121/granthaalayah.v5.i2.2017.1741.

\section{Introduction}

Organization is a societal arrangement of people, an association or else an institution that has a specific goal. There may be several types of organizations such as; governments, nongovernmental organizations, armed forces, corporations, international organizations, charities, universities, partnerships, non-profit organizations. Ultimate goal of the organizations vary from 
organization to organization. Just as goal of the armed forces is to protect the country, universities goal is to give proper education.

An organization is a group of people in an organized form having particular purpose. The Organization to contribute to sustainable growth by means of deliver economic, social, and environmental profit called triple base line at the same time is called a sustainable organization or the organization performing well (Hart \& Milstein, 2003).

There is competition in the overall world, and with the passage of time, consumer's demand changes quickly as well as the organization environments changes also quickly because business cannot survive in the market without changes therefore changes are must for the companies to survive in the market. (Shaharoun, Laosirihongthong, Yusof, \& Zukan, 2010).

To stay alive in the intense competition it's hard for businesses and must bring changes and start some advance operation management practices which is effective for the organization (Hung, 2007).

Pakistan telecommunication companies are facing intense competition, because of the industries booming players, who want to capture the big share of market and to increase the performance of the organization; therefore they are innovating in their processes, products also in their organizations, in order to get the big share (Hart \& Milstein, 2003).

Organization performance includes real productivity or outcome of a business which is calculated in opposite to its planned productivity or targets and aims. Organization performance has been defined as the capability of firm to accomplish its goals and objectives with the help of talented administration, good governance and have a constant rededication to accomplish business objectives (Mahapatro, 2013).

With the passage of time organizations are facing growing trends, it has become the essential need of the organization to take on the operations efficiently, world is moving with a rapid pace and it has become a global village and to compete with organizations and in order to move forward it is utmost necessary that organizations should implement such kind of healthy practices that should help produce maximum outputs (Arshad, Asif, \& Baloch, 2012).

The businesses that perform well are developed according to the needs and wants of the targeted clients and the product they are offering should be different from the competitor product and also have more effectiveness as compare to the competitor and that product helps you to build competitive advantage (Prahalad \& Hamel, The core competence of the corporation, 2011).

Understanding the relationship among innovation performance of the organization in both small and large firms is appropriate for researchers, also for the decision makers, policy makers and managers of small and large companies. The subject of understanding innovations and their relation with organization performance becomes even more important in recent past years, rationale is to encourage firms to do innovation that will lead to a better economic performance (Kemp \& Folkeringa, 2003). 
This study is concerned with the measurement of the performance of the telecommunication organizations of Pakistan when innovations are made in process of the organization, innovation in the product offered by the company and also organizational innovation.

\subsection{Significance of the Study}

This study study be conduct toward identify the impact of product innovation, procedure innovation and organization improvement and having moderating impact of organizational cultural organizational presentation into telecom industry of Pakistan. As independent variables which affect organization presentation be innovation so as to be; item for consumption innovation, progression innovation and organization innovation, so this research is conduct toward discover absent how these variables affect the performance of the organization. After the end of this exacting investigation, conclusion will discover away the important impact of these innovations with the moderating impact of organizational culture activities which comes into play in performance of the organization.

This study will help the decision makers of those organizations who will be practicing these three kinds of innovations i.e. Product innovation, Process innovation and Organization innovation. So with the help of the conclusions which will be generated later, decision makers can make their decisions of applying innovations in their organizations carefully because results will help them to see which innovation is contributing positively to the performance of the organization. It has also academic significance in way that it will help the new researchers who will be conducting the research in the similar areas.

\subsection{Identification of Gap}

A study was done on the connection stuck between innovation and industry performance in Pakistan industry context which indicate some important limitations and also gap for future studies. It suggests that further studies must conduct research on innovation, environmental performance and business performance. The study also suggest that moderating impact was not measured in the study and future studies need to examine it, the study also suggest that future studies can be conducted in other services and manufacturing domains such as air transportation, hospitality, telecom etc (Cheng, Yang, \& Sheu, 2014).

The past studies suggests that the researchers in future can conduct research on organization culture, knowledge management, knowledge sharing as a moderating variable to measure the moderating impact on organization performance (Wei, Ming-Lang, \& Kim, 2014).

On the basis of these recent gaps a model and a theoretical framework of the study is developed. This study includes five important variables which identified from other studies gaps. Product innovation, process innovation and organization innovation are independent variables where organizational culture is moderating variable and organizational performance is dependent variable. 


\subsection{Hypotheses}

H1: Product innovation has an optimistic impact on organization performance.

H2: Process innovation has an optimistic impact on organization performance.

H3: Organization innovation has an optimistic impact on organization performance

H4: Organization culture has a moderating impact between product innovation as well as organization performance.

H5: Organization culture has a moderating impact between process innovation as well as organization performance.

H6: Organization culture has a moderating impact linking organizational innovation and organization performance.

\section{Literature Review}

\subsection{Organizational Performance}

Organization performance includes real productivity or outcome of a business which is calculated in opposite to its planned productivity or targets and aims. Organization performance has been defined as the capability of firm to accomplish its goals and objectives with the help of talented administration, good governance and have a constant rededication to accomplish business objectives (Mahapatro, 2013). Organizational performance is a sign which deal how well a business complete its goals. Organizational performance is one of the most key constructs in the research of management (Ho, 2008).

Researchers thought vary in terms of defining organization performance most of the researchers used the term performance to state the collection of measurement of input and output efficiency and transactional efficiency (Shahzad, Luqman, Khan, \& Shabbir, 2012).

Organization performance is a very wide concept that encompasses different dimensions of management, operational and competitive excellence of an organization and its activities. Except financial performance there are some non-financial performance indicators that have been noted in past studies to improve understanding of organization performance, such as market performance and customer satisfaction (Chen \& Quester, 2006).

\subsection{Innovation}

The term innovation generally includes three types of innovations i.e. Product innovation, process innovation and organizational innovation (Halila \& Rundquist, The development and market success of eco-innovations, 2011). Innovation, green innovation, environmental innovation or sustainable innovation is usually used to find out those innovations that play their part to a sustainable atmosphere through the development of ecological improvements (Becker \& Egger, 2013). Support and maintenance for the development and transmission of more ecological fit processes, products, organizational models and systems can direct to improvements in the living environment of present and future generations (Halila \& Rundquist, The development and market success of eco-innovations, 2011). Innovation is also known as environmental 
innovation, consisting of any kind of product, process or organizational innovation that adds something towards sustainable development (Doran \& Ryan, 2014).

Innovation is where organizations adapt or develop innovations which diagnose, observe decrease or prevent environmental problems. While conventionally so many managers and economists considered innovation as an extra burden of the cost for the firm, this is no longer the case now days (Doran \& Ryan, 2014).

The need and demand for innovation has been augmented because of the requirement to deal with today's different environmental challenges. Innovation refers to the process of creating and developing ideas, way of operation, products and processes that assist in decreasing environmental burdens or reaching environmental sustainability targets (Rennings \& Zwick, 2002).

According to Halila \& Rundquist (2011) the ever escalating stress from the government and market concerning mechanized sustainability, developing an effectual and efficient innovation program and creation it a permanent component of a firm's management programs is significant. When it comes to practice, there are various types of innovations; product innovation, process innovation and organizational innovation. While every kinds of innovation have its own determinants, attribute plus contribution to business performance, it is not too successful to implement innovations without a holistic view (Cheng, Yang, \& Sheu, 2014).

\subsection{Product Innovation}

Product innovation is the improvement of original goods, modify in design of recognized goods, or exercise of fresh supplies in the construct of recognized goods (Alegre, Lapiedra, \& Chiva, 2006). As define by Peters (2009). Product innovation which is latest and in the past it was unfamiliar to the marketplace the business operate in. Product innovation is defined as the new product which is totally diverse from the old product and there is an idea that phrase of product innovation goes hand in hand with phrase of newness (Herrmann, Tomczak, \& Befurt, 2006).

According to the J.E. \& Elsenbach (2007) product innovation is a process which involves the practical design, research and development, administration and marketable actions which concerned in the promotion of the novel good. The product innovation is the main factor for the business development and performance of the business product innovation method is measured component of new product Development mostly the companies earn profit in future with the help of product innovation (Wheelwright, 1992).

In business perspective product innovation include a new products invention, quality improvements and technical specification given to a product, or the addition of new materials, components or valuable functions into an existing product. It covers the enhancement of goods and services or the development of the new categories (Rennings, Andreas, Kathrine, \& Esther, 2006). According to Alegre, Lapiedra, \& Chiva (2006) in recent times there is highly aggressive and forceful atmosphere, the product innovation is highly explored and its highly important to survive, product innovation is mostly the outcome of the three major inclinations; high worldwide competition split, challenging marketplace and third one is the difference and quickly 
changing in the technologies. Product innovation can engage a new or significantly improved product, whose distinctiveness may be significantly different due to use of knowledge, new technologies or materials (Rogers M. , 1998).

According to Lo (2014) the business capability to produce constant flow of the product innovations is the highly significant to run the business or to improve the performance of the business or for the growth of the business, and product innovation is crucial for the business to survive in the market and to capture the market share due to huge competition and day by day competition increases in the market. Due to the high competition the life of the product decreases because of the huge competition and product innovation. So mostly the main focus of the businesses is on the innovation of the product either to improve the product or to develop the new product (Alegre, Lapiedra, \& Chiva, 2006).

\subsection{Process Innovation}

Process innovation is explained as new or enhanced tools, equipments, materials, and other technologies that directly affect the firms that are practicing innovations; those firms' produces the goods that are further sold in the market. There is big difference between process innovations and product innovations, which is; new or improved product technologies that the organization sells for the satisfaction of customers or its clients (Bogers, 2009). Process innovation means the implementation of a fresh or partially enhanced manufacturing/production or deliverance system. It enables the production of a given amount of output that is goods and services with less input. The later can be interpreted in terms of the eco-efficiency (Raymond, Aaron, \& Bertha, 2006).

A type of innovation which has received minor attention in the literature but it has become pretty important in current years. A process innovation is the adoption of new or considerably better production methods, having methods of final product delivery (Rogers M. , 1998).

Process innovation ranges from incremental changes to more radical change. Process innovation brings important amendments in equipment, techniques or software. Process innovations strive to reduce unit cost of manufacturing or delivery, to increase value and worth, or to manufacture or deliver new or more improved products (Brown \& Frame, 2004). Process innovation can play a very important strategic role. It enables to manufacture something that others cannot, or to formulate in a way better than other competitor firms. By process innovation companies can create a very helpful competitive advantage (Hall \& Andriani, 2002).

\subsection{Organization Innovation}

An organizational innovation is the execution of the novel organizational procedure in the industry organization practices, workplace business, or outside relations (Angel, Meroño-Cerdan, \& López-Nicolas, 2013). Organizational innovation is like outsourcing, partnership, subcontract plus organization work practice such as quality management, reengineering, and lean management. Organizational innovation is serious outcome for the business and a foundation to create value (Thakur, Hsu, \& Fontenot, 2012). 
The organizational innovation is wide theory or thought that include many concepts such as strategic, structural and behavioral scope, there is no accord on this defined definition (Mothe \& Nguyen-Van, 2015). Many studies or many researches include the all types of organizational innovation in one side and on the other side some of the researches distinguished that organizational innovation is a technological innovation, and define the difference between the technological and non-technological innovation, but mostly organizational innovation is the improvement or change in the organization practices and knowledge management in the industry or the workplace of the firm (Haneda, Motheb, \& Thic, 2014).

Those firms which are engaged in creativity or organizational innovation has many objectives behind it such as to enhance the value of the business, to earn more profit, enhance the performance of the organization and minimize the organizational cost. It also strive to enhance the place of work satisfaction and also labor productivity and get the access to non-tradable assets like a non-codified information and lower the cost of the goods (Jurado, Gracia, \& Fernández-de-Lucio, 2009). Other factors may be reasons of the organizational innovation related with the marketplace, goods, quality and capability to learn the execution of changes in the organization (Tejada \& Moreno, 2013).

Find out the organization objectives for the innovation and the value can be understood when the market forces that comply the innovation activities like a huge competition and to gain opportunities for to get access in the new business (Mothe \& Nguyen-Van, 2015).

According to Agnieszka \& Woldu (2012) organizational innovation can be more distinguished in two aspects such as intra organizational and inter organization, although the intra organizational innovation happened inside the industry like an execution of teamwork, quality, constantly enhancement in the procedure, certification of departments and occupation inside the organization. On other side inter organizational innovation involves latest business formation within the organization limitations such as latest formations of the organization and atmosphere of the organization and material, buyers or competitors (Armbruster, 2008).

\subsection{Organizational Culture}

The ideology, philosophy, mutual assumption, expectations, attitude, beliefs and norms that tie an organization jointly. The concept of culture is usually linked with foreign, people plus places those are distant, with convention foreign languages and practices (Lund, 2003). An organization culture is reformed and crystallized dynamically and continuously over the period of time. It is a complete collection of shared assumptions about a whole work within a specific profession. These assumptions tell about the concepts such as truth, time, reality and space as these effects individuals and groups (Fogarty, Melville, \& Wilkinson, 1996).

Culture is something that has been done with the people, distinctive quality and approach of an organization. The way things are done and significant non-rational qualities organizations have. An organization is said to have a strong culture, which is mostly defined as they share it on broad basis between the employees (Kim, Lee, \& Yu, 2006). According to Rutherford (2001) it refers to that part of an organization that is intangible, which is used to give cohesiveness. Culture represent signification. In spite of it culture sometimes totally becomes separated from practical 
and it just become shared meaning, assumptions, belief, ethics that simply reside in the mind of employees, therefore it can be both a behavior and a belief.

It is keen to understand organizational traditions for the reason that it is fundamental to study what is going on in organization, how to correctly run them and then how to create some improvement in it (Giritli \& Acar, 2007). Most organizational observers and scholars have find out that organizational culture has a leading results on the product and long lasting usefulness of an organization.

\section{Research Methodology}

\subsection{Research Approach}

Research approach can be define as the procedures and strategy that provide the fundamentals concerning broad assumption to in depth method of date gathering, analysis, and interpretation (Michal, 2011). Descriptive approach has been used in this research and hypothesis will also be tested. An explanatory approach can be defined as an approach in which researcher tries to joint thoughts to recognize cause and effect. This research approach looks at how things are upcoming also interacting with each other (Cohen, Manion, \& Morrison, 2007). While there are very few studies that have been conducted in the past concerned with this study and these variables, fundamentally researchers have to find out and figure out the way these variables behave and results will be bought in front. In this regard, questionnaire is the most feasible option for the problem to be understood that has been carried out in the research. To find out performance as well as association of the variables with each other, hypothesis testing was used.

\subsection{Study of the Population}

Telecom companies of Pakistan are selected as the population for this research. Major telecom companies including Mobilink, Ufone, Zong, Warid and Telenor are the part of population.

\subsection{Sample Size}

A sample of 200 questionnaires was filled from employees that are concerned with innovation in telecom industry present in Islamabad and Rawalpindi to make sure reasonable response. Employees at telecom sector are chosen in this regard because they are well familiar with the innovations and the performance of the organization.

\subsection{Data Collection Method}

\subsubsection{Primary Data}

Primary data was collect beginning to end through questionnaires, which was distributed by researchers among the target population. 


\subsection{Data analysis Technique}

Through SPSS v.20 software data was analyze and then results are declared in this paper, with the help of software data was cautiously analyze and all the related techniques were applied to obtain the results.

\section{Data Analysis and Results}

\subsection{Demographical Statistics}

Table 1: This table helps in explanation respondents frequencies demographically in percentage.

\begin{tabular}{|c|c|c|c|}
\hline \multicolumn{4}{|c|}{ Demographic Analysis } \\
\hline & & Frequencies & Percentage \\
\hline \multirow{2}{*}{ Gender } & Male & 113 & 56.5 \\
\hline & Female & 87 & 43.5 \\
\hline \multirow{3}{*}{ Age } & 25 & 83 & 25.7 \\
\hline & $26-35$ & 107 & 45.7 \\
\hline & beyond 45 & 10 & 25.7 \\
\hline \multirow[t]{3}{*}{ Education } & Intermediate & 8 & 4 \\
\hline & Graduate & 22 & 11 \\
\hline & Post-Graduate & 170 & 85 \\
\hline \multirow{3}{*}{ Position } & Managerial & 27 & 13.5 \\
\hline & Middle Managerial & 5 & 2.5 \\
\hline & $\begin{array}{l}\text { Supervisor/ support } \\
\text { staff }\end{array}$ & 113 & 81.5 \\
\hline \multirow{5}{*}{ Experience } & Fewer than 1 year & 64 & 32 \\
\hline & $1-2$ years & 36 & 18 \\
\hline & 3-4 years & 15 & 7.5 \\
\hline & 5-6 years & 57 & 28.5 \\
\hline & More than 7 years & 28 & 14 \\
\hline
\end{tabular}

This table 1 shows the percentage and frequencies of respondents' demographics in this study. Above table shows that there $56.5 \%$ male and $43.5 \%$ female respondents participated in this study, respondents have different age, education and experience. Table shows that $25.7 \%$ are below 26 years age, $45.7 \%$ are from age bracket of 26-35 and 25.7 are above the age of 45 years. $4 \%$ have intermediate background, $11 \%$ are graduate and $85 \%$ are post-graduate. 


\subsection{Expressive Analysis}

Table 2:

\begin{tabular}{|l|l|l|l|l|l|l|}
\hline \multicolumn{6}{|c|}{ Descriptive data } \\
\hline & Smallest & Highest & Mean & S.D. & Skewness & Kurtosis \\
\hline & & & & & & \\
\hline PI & 3 & 5 & 4.16 & .516 & -.068 & -.422 \\
\hline PCI & 3 & 5 & 4.03 & .488 & -.043 & -.949 \\
\hline OI & 3 & 5 & 4.05 & .521 & -.278 & .114 \\
OC & 3 & 5 & 4.07 & .452 & -.099 & -.709 \\
OP & 3 & 5 & 4.07 & .482 & -.354 & -.106 \\
\hline \hline
\end{tabular}

In descriptive examination table 2 mean show the average distribution. Standard deviation shows the data stretch on or after the mean. Skewness and Kurtosis shows the normality of data which range from $(-1+1),(-3+3)$ respectively. (Andy, 2013). Skewness values in this table for all variables lies in among the range so statistics is usual for these variables and right entered.

\subsection{Reliability Analysis}

\section{Reliability Analysis of Pilot Study}

Table 3:

\begin{tabular}{|l|l|l|l|}
\hline Scale Measurement for Pilot Test $(\boldsymbol{N}=20)$ \\
\hline Variables & Type & $\begin{array}{l}\text { No. of } \\
\text { items }\end{array}$ & Cronbach's alpha \\
\hline Product innovation & IV & 5 & 0.802 \\
\hline Process innovation & IV & 5 & 0.811 \\
\hline Organizational innovation & IV & 5 & 0.867 \\
\hline $\begin{array}{l}\text { Organizational culture } \\
\begin{array}{l}\text { Organizational } \\
\text { performance }\end{array}\end{array}$ & MV & 5 & 0.857 \\
\hline
\end{tabular}

In above mention table 3 of pilot study, the value of Cronback $\alpha$ of each variable is above 0.7 which means the data is reliable (Nunnally, 1978). The acceptable result of reliability analysis allows researchers to continue research study for further procedure. 


\section{Discussions}

\begin{tabular}{|l|l|}
\hline $\begin{array}{l}\mathrm{H}_{1}: \text { Product innovation has an optimistic impact on organization } \\
\text { performance. }\end{array}$ & Accepted \\
\hline $\begin{array}{l}\mathrm{H}_{2}: \text { Process innovation has an optimistic impact on organization } \\
\text { performance }\end{array}$ & Accepted \\
\hline $\begin{array}{l}\mathrm{H}_{3}: \text { Organization innovation has an optimistic impact on organization } \\
\text { performance. }\end{array}$ & Accepted \\
\hline $\begin{array}{l}\mathrm{H}_{4} \text { : Organization culture has moderating impact between product } \\
\text { innovation and organization performance. }\end{array}$ & Accepted \\
\hline $\begin{array}{l}\mathrm{H}_{5}: \text { Organizational culture has moderating impact between process } \\
\text { innovation and organizational performance. }\end{array}$ & Accepted \\
\hline $\begin{array}{l}\mathrm{H}_{6}: \text { Organizational culture has moderating impact between } \\
\text { organization innovation and organization performance. }\end{array}$ & Accepted \\
\hline
\end{tabular}

\section{Conclusion}

Results showed that product innovation, process innovation and organizational innovation has a positive impact on organization performance. Study also indicates that moderation effect of organization culture on the connection of product innovation with organizational performance is positive. The moderation effect of organization culture on the connection of process innovation with organization performance be optimistic. In last the moderation effect of organization culture on the connection of organizational innovation with organization performance is also positive. Results will help the decision makers in telecom industry when they will practice innovation in their organizations that will affect the performance of the organization.

\subsection{Managerial Implications}

This study presents a useful framework that shows how different types of innovations such as; product innovation, process innovation and organizational innovation impact the performances of the organization which is useful for the decision makers of the telecom industry of Pakistan. Results will help those decision makers who will practice innovation in their firms, with the help of this paper they will now have the basic information about how innovation affects organization performance in telecom sector, which will prove positively to the organization.

\subsection{Academic Implications}

This study contributes to the literature and provides a valuable framework for the researchers as well to study the innovation, organizational culture and their relationship with organizational performance. 


\subsection{Direction for Future Research}

This study is limited to just three types of innovations; process innovation, product innovation and organizational innovation as independent variables, and organizational culture as moderating variable. Further study can be done on green innovation, environmental innovation or sustainable innovation and it can also include knowledge management and knowledge sharing as well.

\section{References}

[1] Alegre, j., Lapiedra, R., \& Chiva, R. (2006). A measurement scale for product innovation performance. European Journal of Innovation management, 9 (4), 333-346.

[2] Al-Matari, E. M., Al-Swidi, A. K., \& Bt Fadzil, F. H. (2014). The Measurements of Firm Performance's Dimensions. Asian Journal of Finance \& Accounting, 6 (1).

[3] Angel, L., Meroño-Cerdan, \& López-Nicolas, C. (2013). Understanding the drivers of organization innovation. The Service Industries Journal, 33 (13), 1312-1325.

[4] Armbruster, H. (2008). Organisational innovation The challenge of measuring non-technical innovation in large scale surveys. European journal.

[5] Arshad, S., Asif, R., \& Baloch, M. A. (2012). The impact of "Fairness" In working conditions on organizational performance in Pakistan telecommunication companu, limited, Pakistan. International Journal of Economics adn Management Sciences, 2 (4), 10- 19.

[6] Becker, S. O., \& Egger, P. H. (2013). Endogenous product versus process innovation. Empir Eccon (44), 329-354.

[7] Bogers, M. (2009). The Sources of Process Innovation in User Firms. Journal of Management.

[8] Bozena, P., Jens, J. D., \& Jörgen, A. E. (2003). Implementing ISO 14000 in sweden: motives, benefits and comparisons with ISO 90000. International Journal Of Quality and Management, 20 (5), 585-606.

[9] Brettel, M., Mauer, r., Engelen, A., \& Küpper, D. (2012). Corporate effectuation: Entrepreneurial action and its impact on R\&D project performance. Journal of Business Venturing, 27 (2), 167-184.

[10] Broad, M. L. (2006). Improving performance in complex organizations. Industrial and Commercial Training, 38 (6), 322-329.

[11] Brown, C. J., \& Frame, P. (2004). Small Business Innovation Management. Intrnational Journal of Innovation and Learning, 2 (3), 209-224.

[12] Cavaco, S., \& Crifo, P. (2014). CSR and financial performance: complementarity between environmental, social and business behaviours. Applied Economics, 46 (27), 3323- 3338.

[13] Chen, S. C., \& Quester, P. G. (2006). Modeling store loyalty: perceived value in market orientation practice. journal of service marketing , 20 (3), 188-198.

[14] Cheng, C. C., Yang, C.-1., \& Sheu, C. C. (2014). The link between eco-innovation and business performance. Journal of Cleaner Production (64), 81-90.

[15] Cheng, Y. (2014). Links between Transformational Leadership and Organizational Performance in Colleges and Universities: Mediating Effects of Organizational Innovation. Published by Atlantis Press.

[16] Cohen, L., Manion, L. L., \& Morrison, K. (2007). Research Methods in education (Vol. 10).

[17] Cortes, R. G., Roldan, R. E., Barragan, f. J., Neggy, S., \& Belaud, J. P. (2012). Toward an ecoinnovative method based on a better use of resources. Journal of Cleaner Production (32), 101113.

[18] Doran, J., \& Ryan, G. (2014). Eco-Innovation - does additional engagement lead to additional rewards? International Journal of Social Economics, 41 (11), 1110-1130. 
[19] Ennen, E., \& Richter, A. (2010). The Whole Is More Than the Sum of Its Parts- Or Is It? A Review of the Empirical Literature on Complementarities in Organizations. journal of management , 36, 207-233.

[20] Erkutlu, H. (2011). The moderating role of organizational culture in the relationship between organizational justice and organizational citizenship behaviors. Leadership \& Organization Development Journal, 32 (6), 532-554.

[21] Fotopoulos, C. V., \& Psomas, E. L. (2010). The structural relationships between total quality management factors and organizational performance",. The TQM journal, 22 (5), 539-552.

[22] Garland, R. (2002). Estimating Customer Defection in Personal Retail Banking. The Journal of Bank Marketing, 20 (7), 317-325.

[23] Gavrea, C., Ilie, 1., \& Stegrean, R. (2011). Determinanats of organizational performace. Management and Marketing, 6 (2), 285-300.

[24] Giritli, H., \& Acar, E. (2007). Organizational culture: the case of Turkish construction industry. Engineering, Construction and Architectural Management, 14 (6), 519-531.

[25] Gray, B. J., Matear, S., \& Matheson, P. K. (2002). Improving service firm performance. Journal of Services Marketing, 16 (3), 186-200.

[26] Halila, F., \& Rundquist, J. (2011). The development and market success of eco-innovations. European Journal of Innovation Management, 14 (3), 278-302.

[27] Hall, R., \& Andriani, P. (2002). Managing Knowledge for Innovation. Long Range Planning (35), 29-48.

[28] Haneda, N., Motheb, C., \& Thic, T. U. (2014). Firm persistence in technological innovation: the relevance of organiztional innovation. Economics of Innovation and New Technology, 23 (5), 490-516.

[29] Hart, S. L., \& Milstein, M. B. (2003). Creating Sustainable Value. Academy of Management Executive, 17 (2), 56-69.

[30] Hartmann, A. (2006). The role of organizational culture in motivating innovative behaviour in construction firms. Construction Innovation, 6 (3), 159-172.

[31] Henderson, R. (2006). The Innovator's Dilemma as a Problem of organizational competence. Product Innovation Management, 23, 5-11.

[32] Herrmann, A., Tomczak, T., \& Befurt, R. (2006). Determinants of radical product innovations. European Journal of Innovation Management, 9 (1), 20-43.

[33] Ho, L.-A. (2008). "What affects organizational performance? The linking of learning and knowledge management. Industrial Management \& Data Systems, 108 (9), 1234 - 1254.

[34] Hung, h.-m. (2007). Influence of the Environment on Innovation Performance of TQM. total quality management, 18 (7), 715-730.

[35] Jurado, J. V., Gracia, A. G., \& Fernández-de-Lucio, I. (2009). Does external knowledge sourcing matter for innovation? Evidence from the Spanish manufacturing industry. Industrial and Corporate Change, 180 (4), 637-670.

[36] Kemp, R. G., \& Folkeringa, M. (2003). Innovation and firm performance.

[37] Kim, S., Lee, J., \& Yu, k. (2006). Corporate culture and organizational performance. Journal of Managerial Psychology, 19 (4), 340-359.

[38] Lai, M.-F., \& Lee, G.-G. (2007). Relationships of organizational culture toward knowledge activities. Business Process Management journal, 13 (2), 306-322.

[39] Letangule, S. L., \& Letting, N. K. (2012). Effect of Innovation Strategies on Performance of Firms in the Telecommunication Sector in Kenya. Journal of Management, 2 (3).

[40] Liang, D., Ma, Z., \& Qi, L. (2013). Service Quality and Customer Switching Behavior In China's Mobile Phone Service Sector. Journal of Business Research, 66 (8), 1161-1167.

[41] Lund, D. B. (2003). Organizational culture and job satisfaction. ournal of Business \& Industrial Marketing , 18 (3), 219-236.

[42] Mahapatro, B. B. (2013). Organization performance. Human resource managemnet, 272- 279. 
[43] Maletic, M., Maletic, D., Dahlgaard, J. J., Dahlgaard-Park, S. M., \& Gomiscek, B. (2014). The Relationship between Sustainability-Oriented Innovation Practices and Organizational Performance: Empirical Evidence from Slovenian Organizations. Research paper, 47 (1).

[44] Michal, B. P. (2011). Nonprobability sampling. Encyclopedia of survey Research Methods 2008. SAGE.

[45] Mothe, C., \& Nguyen-Van, P. (2015). organizational innovations for technological innovation: the role of knowledge management practices. apllied economics .

[46] Ogbonna, E., \& Harris, L. C. (2000). Leadership style, organization culture and performance. The International Journal Of HRM, 11 (4), 766-788.

[47] Ota, M., Hazama, Y., \& Samson, D. (2013). Japanese Innovation Processes. International Journal of Operations \& Production Management, 33 (3), 275 - 295.

[48] Owen, K., Munday, R., Guild, W., \& Guild, R. (2001). Creating and sustaining the high performance organization. Managing Service Quality: An International Journal, $11 \quad$ (1), 1021.

[49] Pokharel, M. P., \& Choi, S. o. (2015). "Exploring the relationships between the learning organization and organizational performance. Management Research Review, 38 (2), 126-148.

[50] Prahalad, C., \& Hamel, G. (2011). The core competence of the corporation. harvard business review , 68 (3), 79-91.

[51] Prajago, D. I., \& McDermot, C. M. (2005). The relationship between total quality management practices and organizational culture. International Journal of Operations \&amp; Production Management, 25 (11), 1101-1122.

[52] Ravichandran, J. (2007). Cost-based process weights for DPMO and the overall performance of an organization. The TQM Magazine, 19 (5), 442-453.

[53] Raymond, C., Aaron, B., \& Bertha, L. (2006). Eco-efficiency and SMEs in Nova Scotia, Canada. Journal of cleaner Production, 14 (6-7), 542-550.

[54] Raza, K. (2014). Application of Network Closure Theory towards Firm innovation in Pakistani Telecom Sector. Scholarly Journal of Business Administration, 8 (2), 170- 178.

[55] Rennings, K., Andreas, Z., Kathrine, A., \& Esther, H. (2006). The Influence of Different Characteristics of the EU Environmental Management and Auditing Scheme On Technical Environmental Innovations And Economic Performance. Ecological Economics, 57 (1), 4559.

[56] Rogers, P., \& Blenko, M. (2006). The high-performance organization: making good decisions and making them happen. Handbook of Business Strategy, 7 (1), 133-142.

[57] Rondeau, K. V., \& Wagar, T. H. (1999). Hospital choices in times of cutback: the role of organizational culture". Leadership in Health Services, 12 (3), 14-22.

[58] Sadikoglu, E., \& Zehir, C. (2010). Investigating the effects of innovation and employee performance on the relationship between TQM practices and firm performance an empirical study of Turkish firms. International journal of production economics, $127 \quad$ (1), 13-26.

[59] Shaharoun, A. M., Laosirihongthong, T., Yusof, S., \& Zukan, N. (2010). "Proposed Relationship of TQM and Organizational Performance using Structured Equation M odeling.”. total quality management and excellence, 21 (2), 185-210.

[60] Shahzad, F., Luqman, R. A., Khan, A. R., \& Shabbir, L. (2012). Impact of Organizational Culture on Organizational Performance. Interdisiplinary journal of contemporary research in business, 3 (9).

[61] Sila, ,. I. (2007). "Examining the Effects of Contextual Factors on TQM and Performance through the Lens of Organizational Theories: an emperical study journal of operation management, (1), 83-109.

[62] Skaržauskien, A. (2010). Managing complexity: systems thinking as a catalyst of the organization performance. Measuring Business excellence, 14 (4), 49-64. 
[63] Slack, N., Chambers, S., \& Johnston, R. (2006). Operations and Process Management: PrinciplesPractice for Strategic Impact. Harlo: Prentice Hall.

[64] Stashevsky, S., \& Elizur, D. (2000). The Effect of Quality Management and Participation in Decision-making on Individual Performance. journal of quality management , 5, 53-

[65] Teece, D. J., Pisano, G., \& Shuen, A. (1997). Dynamic capabilities and strategic management. strategic management journal , 18 (7), 509-533.

[66] Tejada, P., \& Moreno, P. (2013). Patterns of innovation in tourism and Medium-size Enterprises. The Service Industries Journal, 8 (7), 749-758.

[67] Thakur, R., Hsu, S. H., \& Fontenot, G. (2012). Innovation in healthcare: Issues and future trends. Journal of Business Research, 65 (4), 562-569.

[68] Thiagaragan, T., Zairi, M., \& Dale, B. G. (2001). proposed model of TQM implementation based on an empirical study of Malaysian industry. international journal of quality and reliability management , 18 (3), 289-306.

[69] Tidd, J. (2001). Managing Innovation: Integrating Technological, Market and Organizational Change.

[70] Uma, K., Vinod, K., Danuta, d. G., \& Franck, C. (2009). Continuous Improvement of Performance Measurement by TQM adopters. Total quality management and business excellence, 20 (6), 603-616.

[71] Van Kessel, F. G., Oerlemans, L. A., \& Van Stroe-Biezen, S. A. (2014). No creative person in an island: Organizational culture, academic project-based creativity,and the mediating role of intraorganizational social ties . SAJEMS Special Issue, 17, 46-69.

[72] Wei, P. W., Ming-Lang, T., \& Kim, H. T. (2014). A business process management capabilities perspective on. Total Quality Management \& Business, 25 (6), 602-617.

[73] Wheel wright, S. c., \& Clark, K. B. (1992). Revolutionizing Product Development - Quantum Leaps in Speed, Efficiency, and Quality. The Free Press, New York, NY.

[74] Zakuan, M. N., Yusof, S. M., Laosirihongthong, T., \& Shaharoun, A. M. (2010). Proposed relationship of TQM and organizational performance using structured equation modeling. total quality management , 21 (2), 185-203.

*Corresponding author.

E-mail address: aksuhag@ @miu.edu.pk 